\title{
Benefits and Drivers of Nonprofit Revenue Concentration
}

Nonprofit and Voluntary Sector Quarterly

(C) The Author(s) 2017

Reprints and permissions: sagepub.com/journalsPermissions.nav

DOI: $10.1177 / 0899764017713876$ journals.sagepub.com/home/nvs

(S)AGE

\section{Georg von Schnurbein' and Tizian M. Fritz',2}

\begin{abstract}
Nonprofit organizations (NPO) rely on a diverse mix of revenue sources. The existing literature mainly supports diversification among different revenue sources as desirable because it enables organizational stability. Using a new data set of over 200 Swiss fundraising charities, we prove the opposite to be true: organizations that displayed a higher degree of revenue concentration grew stronger between 2005 and 20I2. We identify factors influencing the organization's capital and revenue structure. These factors can be divided into "nature" and "nurture" factors, which allows us to demonstrate which of them may be actively influenced by an organization's management and which stem from conditions of the organization that cannot be readily overcome by managerial interventions (such as age, size, and legal form). Revenue concentration is positively influenced both by an organization's geographical range of activity and dependence on its primary revenue source, and negatively influenced by board size and diversity.
\end{abstract}

\section{Keywords}

financial stability, revenue growth, nonprofit financials, revenue concentration, revenue diversification

\section{Introduction}

Nonprofit organizations (NPOs) rely on a diverse mix of income sources (Wilsker \& Young, 2010). Typically, these sources can be divided into four major categories: (a) income from donations (from private individuals and enterprises), (b) income from

\footnotetext{
'University of Basel, Basel, Switzerland

${ }^{2}$ Swiss Science and Innovation Council, Bern, Switzerland

Corresponding Author:

Georg von Schnurbein, Center for Philanthropy Studies (CEPS), University of Basel, Steinengraben 22,

Basel CH-405I, Switzerland.

Email: georg.vonschnurbein@unibas.ch
} 
government (through grants, contracts, and services), (c) income from own revenues (such as service fees and products sold), and finally (d) income from investments. Existing research finds broad support for diversification among these sources, and diversification is understood to have a positive influence on the financial stability and growth of NPOs (see Carroll \& Stater, 2009; Froelich, 1999; Tuckman \& Chang, 1991; Wicker \& Breuer, 2014). However, in their article, Chikoto and Neely (2014) prove the opposite to be true, as also previously proposed by Foster and Fine (2007). These authors found that a "revenue concentration strategy generates a positive growth in . . . total revenue" (p. 570).

As formulated in the benefits theory of nonprofit finance (Wilsker \& Young, 2010), an organization's main sources of revenue may depend on the nature of its produced goods. Therefore, the question of diversification or concentration may also be a question of an organization's range of offered and produced products. As these products are often directly tied to the organization's underlying mission, they may be perceived as being part of an organization's nature - "organizational conditions that cannot readily be overcome by management response" (Hager \& Brudney, 2011, p.137). Factors driving revenue diversification that may be influenced by management, henceforth labeled nurture, are often neglected in existing research. Our article focuses on both the nature and nurture of capital and revenue structure and thus their indirect influences on NPOs' financial growth. To our knowledge, none of the existing studies of the capital and revenue structures of NPOs examine the organizational factors that influence the degree of revenue diversification/concentration and that therefore ultimately influence revenue growth. Hence, the goal of this article is twofold. First, we contribute to the discussion of the influence of the degree of revenue diversification on financial growth in NPOs. Second, we aim to discover the drivers behind revenue concentration and diversification, building on previous work on the benefits theory of nonprofit finance (Wilsker \& Young, 2010) and capital structure theories of nonprofits (Calabrese, 2011; Jegers \& Verschuren, 2006).

In contrast to previous studies, our analysis is based on a new, non-U.S. data set composed of certified Swiss fundraising charities of different legal forms. Given a sample of more 200 charities, we find that these organizations generally demonstrate a high degree of dependence on their primary revenue sources. Our regression analysis shows a significantly negative influence of revenue diversification on logarithmized revenue growth. Furthermore, we enrich the current understanding of nonprofit finance by introducing a set of given or modifiable factors that influence revenue concentration.

Our article is structured as follows. After an overview of the existing literature on nonprofit financial stability, growth, and revenue structures, including the identification of research gaps, we derive our analysis' research method from central nonprofit financial management theories. This section includes the formulation of several hypotheses with regard to organizational growth and revenue diversification. We conclude our methodological discussion with two central regression models. An overview, containing descriptive statistics of our data set, connects our methodological discussion to the presentation of our results. These are subsequently discussed in our 
"Discussion" section. Finally, we conclude our analysis with an outlook on and propositions for future research.

\section{Literature Review}

The ultimate reason for NPOs to increase their financial resources is the enduring pursuit of their charitable missions (Froelich, 1999). However, NPOs face several challenges to their financial management. First, the dominant source of nonprofit revenue is not sales. Depending on their charitable mission, they offer services and products for free or at a below-market rate. Thus, they require other income sources. Second, and as a consequence of the first challenge, NPOs rely on a mix of income sources, but their selection and proportion is not straightforward, and they differ from one organization to another (Wilsker \& Young, 2010). Finally, NPOs are restricted in their abilities to issue debt and pursue external borrowing (Bowman, 2006). NPOs often lack creditworthy assets that would facilitate borrowing. These challenges raise the question of how NPOs can grow if both their accumulation of internal funds and their options for external borrowing are limited.

\section{Theories of Organizational Survival and Growth}

In the past two decades, the size of the nonprofit sector has increased on a global level. Many new NPOs were established, but most notably, the financial resources of NPOs reached an all-time-high. Despite the burgeoning literature on the economic and social relevance of this sector overall, research on growth at the organizational level is scarce. In an early article, James (1983) argues that mission rather than economic self-interest is the major driver of nonprofit growth. Nonprofit managers chose goals based on their missions and then determine their activities. Accordingly, they collect as many financial resources as they need to execute their activities. Hence, NPOs grow in relation to resource enhancement and expansion of activities to achieve their charitable missions (Galaskiewicz, Bielefeld, \& Dowell, 2006; Steinberg, 1993). Research has adopted this perspective on "balancing money and mission" as a primary issue in nonprofit management (Frumkin \& Andre-Clark, 2000; McDonald, 2007).

In the general literature on organizational survival and growth, one finds two prominent theories: resource dependency theory and competitive advantage theory. Resource dependency theory predicts that organizations survive if they manage to secure access to important resources (Pfeffer \& Salancik, 2003). The reason for the constant striving for resources lies in their scarcity and uncertainty. Hence, interactions with other organizations and the requirements of resource providers are necessary for organizational survival and growth (Froelich, 1999). Based on resource dependency theory, diversification is a vital strategy for organizations wanting to remain independent. Thus, research on the financial vulnerability of NPOs predominantly adopts this assumption, (Chang \& Tuckman, 1994; Frumkin \& Keating, 2011) as will be shown in the following section. 
In contrast, the theory of competitive advantage builds on the fundamental assertion that firms survive if they manage to create a surplus through competitive advantage (Porter, 1985). Thus, marketization and professionalization are important strategies for NPOs in light of this theory (Kong \& Prior, 2008; Warnaby \& Finney, 2005). However, the definition of "market" is not very clear for NPOs. In terms of services and sales, NPOs are often not competing through pricing or promotion, as their clients are not paying full price. Hence, the market perspective is more vital in terms of competition for resources, especially in fundraising. Investing in and reporting on successful projects thus addresses both clients' satisfaction and donors' expectations (von Schnurbein, 2016).

The body of literature on nonprofit finance strongly favors the resource dependency perspective, emphasizing the importance of financial stability and reduced volatility (Bowman, 2006; Froelich, 1999; Tevel, Katz, \& Brock, 2015). However, financial health consists of two dimensions: stability and capacity. Stability serves for predictability and reduces financial vulnerability, while the second is defined as "resources that give an organization the wherewithal to seize opportunities and react to unexpected threats" (Bowman, 2011, p. 38). Instead of focusing on financial stability, recent research investigates the ability of nonprofits to build financial resources, as we will show in the following section (Chikoto \& Neely, 2014; Foster \& Fine, 2007). Hence, we identify a research gap regarding the interdependence of revenue diversification and nonprofit growth.

\section{Capital and Revenue Structure}

Although NPOs are not profit-oriented, they must generate revenue to pursue their social missions. Two issues dominate the literature on nonprofit capital structure: borrowing and diversification. Both issues aim at reducing financial vulnerability and increasing predictability (Kingma, 1993). The research on borrowing thus addresses balancing internal funds and external debt. Several researchers have investigated the application of corporate finance theories, especially trade-off theory and pecking order theory (Bowman, 2011; Calabrese, 2011; Jegers, 2011; Yan, Denison, \& Butler, 2009). Although trade-off theory posits that NPOs balance the costs and benefits of debt to obtain an optimal leverage level, pecking order theory states that managers prefer internal funds to external borrowing (Calabrese, 2011).

Jegers and Verschuren (2006) identify three mechanisms that influence nonprofit capital structure: (a) equity constraints, as available funds do not cover investment requirements; (b) agency problems, as managers must be supervised and debt is one mechanism for doing so; and (c) borrowing constraints, as NPOs cannot always borrow even if they are creditworthy. Jegers (2011) finds support for the first two mechanisms, meaning that nonprofit capital structure is explained by the balance of internal versus external funds and through mechanisms of control. Calabrese (2011) finds that NPOs organize their capital structures according to pecking order theory. However, internal funds are not completely used to reduce debt but are partly retained as a rainy day fund. 
Only recently has research begun to further investigate nonfinancial influences on nonprofit capital structure. Jegers (2013), for example, shows that potential agency conflicts between management and the board induce manipulations of reported earnings. He finds that more professionalized organizations with more paid staff have more incentives to manipulate their reports of earnings. Similarly, current research on revenue diversification opens up questions on nature versus nurture in an organizational context.

As stated above, revenue diversification is by far the most common recommendation for financial stability in NPOs. In her seminal work, Froelich (1999) discusses how relying on different revenue sources better supports financial stability because every source has its specific characteristics in terms of volatility, goal displacement, and effects on processes and structures. Measures of revenue diversification are seen as important indicators of an organization's ability to avoid or withstand financial vulnerability (Bowman, 2011; Carroll \& Stater, 2009; Chang \& Tuckman, 1994; Kingma, 1993). Yan et al. (2009) prove that diversified NPOs are more likely to issue debt without necessarily having higher debt ratios. Tevel et al. (2015) support the utility of diversification as risk reduction.

However, increased financial stability comes at the cost of managing and controlling the organization's different revenue sources (Frumkin \& Keating, 2011). Using a sample of Austrian NPOs, Schober, Littich, Schober, and Lintschinger (2011) show that agency costs increase with higher diversification, in some cases disproportionately to the increase in revenue.

Mayer, Wang, Egginton, and Flint (2014) highlight that increased diversification does not always reduce volatility. Kingma (1993) notes that beyond the risk tolerance of the organization, the covariance between the single revenue sources has to be taken into account as well. Even more critical of the effects of diversification are studies by Foster and Fine (2007) and Chikoto and Neely (2014). Foster and Fine (2007) analyze the development of a sample of 144 U.S. nonprofits over the period 1970 to 2003. They conclude that $90 \%$ of 110 nonprofits with annual revenue over US\$50 million managed growth in revenue through the decision to rely on one single type of income source. Based on a much larger sample, Chikoto and Neely (2014) support this finding. They highlight that revenue concentration leads to financial growth and helps to build up financial capacity. They argue that investments in administrative and fundraising costs pay off if concentrated on fewer income sources. Calabrese (2011) emphasizes that "revenue diversification and sources have little effect on a nonprofit's capital structure" (p. 139). Given the current state of discussion, we find it necessary to further investigate the drivers of diversification.

\section{Drivers of Diversification: Nature or Nurture?}

Analyzing the attractiveness of organizations for volunteers, Hager and Brudney (2011) differentiate between the "nature" and "nurture" of influencing factors. Factors that are directly tied to the organization's mission or structure are labeled "nature," whereas 
"nurture" consists of organizational factors influenced by management. In that sense, restricted funds would be labeled nature and unrestricted funds labeled as nurture.

This understanding is supported by the benefits theory of nonprofit finance. Wilsker and Young (2010) argue that the choice of revenue sources is influenced by the goods and services offered by an organization. Hence, public or collective goods are associated with public funding and private donations, whereas individual goods are more likely to be financed by own revenue. Therefore, revenue diversification is not only a result of managerial decisions but is also a consequence of the organization's mission.

(Lu, 2015) finds organizational factors that determine whether or not NPOs receive government funding. Bureaucratic orientation, domain consensus with government, and funding history with government are more important than revenue diversification, professionalization, or board composition.

Other drivers of revenue structure may be found in the governance of an organization. Siciliano (1996) finds support for the positive influence of board size on donations and the negative influence of gender diversity. However, the general management literature shows that women have a positive influence on firm value (Carter, Simkins, \& Simpson, 2003). Size (Suarez, 2011), professionalization (or indirectly, size as a proxy for professionalization, see Hwang \& Powell, 2009), and commercialization (Child, 2010) may be other factors that influence the capital structure of nonprofits. Larger nonprofits have more resources for administrative operations than smaller ones, and thus they tend to be more professional in terms of fundraising, financial management, and accounting.

To conclude, in pursuit of their charitable missions, NPOs are relying on the generation of financial means to survive or even grow. Building on the distinction between nature and nurture, we highlight aspects of control and availability in terms of restrictions on funds, as well as in terms of drivers influencing the diversification of revenue sources. However, existing literature generally fails to analyze nonfinancial influences on nonprofit capital structure.

\section{Method}

The aim of our survey is to improve the understanding of the influence of the degree of revenue diversification on financial growth and to identify distinct drivers of revenue diversification in NPOs. We therefore use two regression models based on the theories and literature discussed above.

\section{Drivers Behind Revenue Growth}

Our first model takes the log of 7-year revenue growth as the dependent variable (see Chikoto \& Neely, 2014). We will test the two central theories of nonprofit growth. First, in light of the results of Chikoto and Neely (2014), we test whether the degree of revenue diversification has an influence on revenue growth. Second, based on competitive advantage theory, we assume that a high proportion of spending on projects, instead of on administration and fundraising, has a positive effect on donors' 
willingness to further support the organizations. This is supported by several authors (for an excellent overview, see Lecy \& Searing, 2015) but also deemed problematic, as "the reliance on overhead ratios . . . may cause a steady and self-perpetuating practice of cost-cutting, which in turn may harm the nonprofit" (Lecy \& Searing, 2015, p. 540). In addition, we introduce two control variables to account for size and age. Therefore, our two central null-hypotheses are formulated as follows:

Hypothesis 1.0 (H1.0): There is no influence of revenue diversification on revenue growth.

Hypothesis 2.0 (H2.0): There is no influence of the relative proportion of revenue directly dedicated to projects on revenue growth.

\section{Drivers Behind Capital and Revenue Structure}

In our search for factors that influence the revenue structure in NPOs, we divide the possible variables identified from our theoretical analysis into two main categories. We do so by applying Hager and Brudney's (2011) distinction between the nature and nurture of NPOs.

Based on the benefits theory of nonprofit finance, the type of products and services an organization offers influences its revenue structure. We propose that in addition to the types of products (and therefore indirectly the organization's mission), there are other organizational factors driving the degree of revenue diversification and that these factors are independent of managerial decisions. First of all, the geographic radius of activity - whether an organization acts on a local, national, or international levelattracts a different type of donor (Purtschert, von Schnurbein, \& Bittel, 2007) and also makes the organization more or less relevant to certain governmental agencies than others. As the radius of activity is very often mentioned in the mission statement or founding documents, this is clearly an aspect of the organization's nature. Our second hypothesis is based on the fact that associations have members while foundations (set up as trusts after Swiss civil law, see von Schnurbein \& Timmer, 2015) do not. Income from members has a significant influence on the revenue structures of NPOs (see Wicker, Longley, \& Breuer, 2015). We therefore include the legal form, as an independent variable based on the organization's nature, in our analysis, as a change of legal form is rather difficult. Finally, the size of an organization heavily influences its ability to hire professional (fundraising) staff. Size is often combined with a higher degree of visibility, which should ultimately influence the revenue structure. As management cannot influence the organization's size on a short- and medium-term level, we will also include this independent variable as part of an organization's nature. These variables lead to the formulation of the following three null-hypotheses, labeled as "nature":

Hypothesis 3.0 (H3.0): There is no influence of the organization's radius of activity on the degree of revenue diversification (taking a national radius of activity as standard, identifying organizations with one dummy for local activities only and one dummy for activities on an international level). 
Hypothesis 4.0 (H4.0): There is no influence of the organization's legal form on the degree of revenue diversification (the dummy variable for the organization being either a foundation, 1 , or an association, 0 ).

Hypothesis 5.0 (H5.0): There is no influence of the organization's size on the degree of revenue diversification (calculated as logarithmized total annual revenue).

In addition to factors that can be considered part of an organization's nature, we introduce another three independent variables that are influenced by managerial decisions (hence, an organization's "nurture"). First, organizations that show consistency in their primary revenue source over time (coded as a dummy variable) should tend to have a higher degree of revenue concentration, as the primary revenue source has proven to be effective, and focusing on that specific source leads to higher expected revenue. This independent variable does not reflect the same information as the dependent variable, as one organization may well have shifted from mainly raising funds through donations to government grants, but may display a similar degree of revenue concentration (hence, the same degree of revenue diversification but no consistency).

Second, we include governance issues as drivers of revenue diversification. Brown (2005) shows a general influence of board performance on organizational performance, including financial stability. Siciliano (1996) proves that an increase in board gender diversity leads to lower levels of donations. Galaskiewicz et al. (2006) argue that more diverse boards connect to more networks in the environment and, thus, are better at securing funds. Finally, the absolute size of the organization's board is expected to have a positive influence on revenue diversification. The findings of Brown (2005) provide evidence that larger boards are better at providing resources. In addition, based on resource dependency theory, larger board size reduces organizational uncertainty (Miller-Millesen, 2003). We summarize the three factors labeled "nurture" in the following null-hypotheses:

Hypothesis 6.0 (H6.0): There is no influence of consistency in primary income source on the degree of revenue diversification (coded as dummy variable).

Hypothesis 7.0 (H7.0): There is no influence of board diversity (measured as Herfindahl-Hirschman Index [HHI] of male and female members) on the degree of revenue diversification.

Hypothesis 8.0 (H8.0): There is no influence of board size (as number of board members) on the degree of revenue diversification.

\section{Regression Models}

Given our two central research questions and corresponding hypotheses, we now formulate two basic regression models. An overview summarizing the two models, including the corresponding literature for the individual hypotheses, can be found in Table 1 at the end of this section. To test drivers behind revenue growth (calculated as the logarithmized percentage of revenue growth between 2005 and 2012), we set up a simple 
Table I. Overview of Two Models Including Respective Literature.

\begin{tabular}{|c|c|c|}
\hline & Model I & Model 2 \\
\hline $\begin{array}{l}\text { Dependent } \\
\text { Variable }\end{array}$ & Revenue growth (7-year, log) & $\begin{array}{l}\text { Revenue Diversification (normalized } \\
\text { HHI, Yan et al., 2009) }\end{array}$ \\
\hline $\begin{array}{c}\text { Independent } \\
\text { Variables }\end{array}$ & $\begin{array}{l}\text { HI Revenue diversification } \\
\text { + Resource Dependency Theory } \\
\text { (Carroll \& Stater, 2009; Chang } \\
\text { \& Tuckman, 1994; Froelich, } \\
\text { I999; Frumkin \& Keating, } \\
\text { 20II; Tuckman \& Chang, I99I; } \\
\text { Wicker \& Breuer, 20I4) } \\
\text { - Competitive Advantage } \\
\text { Theory (Chikoto \& Neely, 20I4; } \\
\text { Foster \& Fine, 2007) } \\
\text { H2 Relative project spending } \\
\text { + Competitive Advantage } \\
\text { Theory (for an overview see } \\
\text { Lecy \& Searing, 20 I5) }\end{array}$ & $\begin{array}{l}\text { Nature (general influence of goods and } \\
\text { services: Wilsker \& Young, 20I0) } \\
\text { H3 Radius of activity } \\
\text { H4 Legal form (dummy for foundation) } \\
\text { Reduction of revenue volatility } \\
\text { through membership income } \\
\text { (Wicker, Longley, \& Breuer, 20I5) } \\
\text { H5 Size (total revenues) } \\
\text { As proxy for professionalization } \\
\text { (Hwang \& Powell, 2009) } \\
\text { Nurture } \\
\text { H6 Consistency in main revenue source } \\
\text { H7 Board diversity (among male and } \\
\text { female) } \\
\text { Women have positive influence } \\
\text { on firm value (Carter, Simkins, \& } \\
\text { Simpson, 2003) } \\
\text { Negative influence of gender diversity } \\
\text { on donations (Siciliano, I996) } \\
\text { Broader networks, better at securing } \\
\text { funds (Galaskiewicz et al., 2006) } \\
\text { H8 Board size (number of members) } \\
\text { Board size positively influences level } \\
\text { of donations (Siciliano, I996) } \\
\text { Bigger boards are better at providing } \\
\text { resources (Brown, 2005) } \\
\text { + Resource Dependency Theory } \\
\text { (Miller-Millesen, 2003) }\end{array}$ \\
\hline $\begin{array}{l}\text { Control } \\
\text { Variables }\end{array}$ & $\begin{array}{l}\text { Size (total revenues) } \\
\text { Age (in years) }\end{array}$ & \\
\hline
\end{tabular}

Note. The nature and nurture distinction in Model 2 is based on Hager and Brudney $(201 \mathrm{I})$. + predicts positive influence on dependent variable; - predicts positive influence on dependent variable. $\mathrm{HHI}=$ Herfindahl-Hirschman Index.

linear regression model that was evaluated using a standard multivariate ordinary least squares (OLS) regression (computed in RStudio ${ }^{1}$ ). The model is specified as follows:

$$
\log \left(\text { growth }_{i}\right)=\beta_{0}+\beta_{1} H H I_{Y a n, i}+\beta_{2} \text { proj }_{\bullet}+\beta_{3} \log \left(\text { size }_{i}\right)+\beta_{4} \text { age }_{i}+\epsilon_{i},
$$

where growth, $\mathrm{HHI}_{\text {Yan }}$, proj., size, and age represent the following categories of (control) variables: revenue growth, revenue diversification, proportion of revenue directly dedicated to projects, organizational size, and age. 
For our second research question, the dependent variable is a proportion, as revenue concentration/diversification is measured using an adjusted HHI, as proposed by Yan et al. (2009). The measure includes four revenue sources (government grants, donations, program revenue, and investment income). We chose this more diversified measure over other modifications, such as the HHI by Carroll and Stater (2009), as a higher differentiation in revenue sources leads to more robust results (Chikoto \& Neely, 2014). The values of the HHI are bound in the unit interval. Standard multivariate OLS regression is not suitable for the analysis of such a variable. First, the estimated values would exceed the unit interval and thus cannot be interpreted. Second, proportions often show accumulation of mass in the extremes and heteroscedasticity around the mean. Logit transformation would solve the problem of the variable being bound in the unit interval. However, it is not clear whether the transformation stabilizes the variance (see Kieschnicke \& McCullough, 2003). We therefore use a beta regression model as proposed by Ferrari and Cribari-Neto (2004), which is specifically designed for data such as proportions and is especially suitable for smaller sample sizes (Kieschnicke \& McCullough, 2003). Beta regression requires the dependent variable to be on the open unit interval, which is given (see data description in the following section). The model's underlying linear regression equation is formulated as follows:

$$
\begin{aligned}
g_{1}\left(\mu_{i}\right)= & \beta_{0}+\beta_{1}{\text { region } . i_{i}}_{i} \beta_{2} \text { region.c }_{i}+\beta_{3} \text { foundation }_{i}+ \\
& \beta_{4} \log \left(\text { size }_{i}\right)+\beta_{5} \text { cons. } . i_{i}+\beta_{6} \text { board.divers. } . i_{i}+\beta_{7} \text { board.size }_{i},
\end{aligned}
$$

where region.i, region.c, foundation, size, cons., board.divers., and board.size represent the following categories of variables: dummy variable for international radius of activity, dummy variable for regional radius of activity, dummy variable for foundation as organizational form, size, consistency in primary income source, board diversity, and board size. Revenue diversification $\left(\mathrm{HHI}_{\text {Yan }}\right)$ as a dependent variable follows a beta distribution:

$$
\begin{gathered}
H H I_{Y a n, i} \sim \mathrm{B}\left(\mu_{\mathrm{l}}, \phi_{i}\right) \\
f\left(H H I_{Y a n} ; \mu, \phi\right)=\frac{\Gamma(\phi)}{\Gamma(\mu \phi) \Gamma((1-\mu) \phi)} H H I_{Y a n}^{\mu \phi-1}\left(1-H H I_{Y a n}\right)^{(1-\mu) \phi-1} .
\end{gathered}
$$

In contrast to common OLS regressions, this model is estimated with a maximum likelihood approach. The model was estimated in RStudio using the package betareg as described in Zeileis, Cribari-Neto, Gruen, and Kosmidis (2015).

\section{Data}

So far, only a few surveys have used non-U.S. data to analyze nonprofit capital structure (Jegers, 2011; Schober et al., 2011; Wicker \& Breuer, 2014). Our sample is based on Swiss charitable nonprofits. The nonprofit sector in Switzerland covers a wide 
range of activities and can be positioned between the liberal and the corporatist models according to the social origins theory of Salamon and Anheier (1996). According to the country report of the Johns Hopkins Comparative Nonprofit Sector Project, there are approximately 100,000 nonprofits active in Switzerland, most of them in social and health services, education and research, and culture and leisure. However, only 2,000 of these organizations collect annual donations of over US\$100,000 (Helmig et al., 2011). Overall, their total revenue adds up to US\$19 billion, divided into 57\% own revenues, 35\% state subsidies, and 8\% private giving (based on data from 2005). However, more recent studies estimate higher revenues from private donations of up to US\$3 billion (von Schnurbein, 2013). As health care as well as research and education are organized and financed predominantly by the state, private donations preferably flow to areas such as social services, international development, and culture.

The typical legal forms are association and foundation. Under Swiss law, the legal type gives no indication of the organization's activities. Thus, a charitable social service agency can be either an association or a foundation. Bearing in mind that our analysis concerns the revenue structure of NPOs, we chose to focus on Swiss fundraising charities that received the Stiftung ZEWO-seal of approval.

The process of certification by ZEWO is based on a self-declaration by the nonprofits and an annual audit by the ZEWO foundation according to its regulations (ZEWO, 2015). In her comparison of nonprofit self-regulation in Europe, Bies (2010) describes ZEWO as compliance self-regulation, covering two aims: "(a) to protect the donors'investments and (b) to serve as a selection mechanism in determining which charities are "bona fide" and deserving of support" (p. 1070). The ZEWO-seal is highly regarded by society, with over 30\% name recognition (Ortmann, Svítková, \& Krnáčová, 2005). Therefore, ZEWO-certified charities not only publish their annual reports online and implement the same accounting standards (Swiss GAAP FER 21, see Eberle \& Müller, 2011), they also have similar motives in raising funds, as they have obtained the ZEWO-seal. Approximately 430 organizations are certified to date, collecting more than two thirds of total private and corporate donations in Switzerland. At the time of the initial data collection, the 2012 annual report was the most recently available. To cover the longest possible time span given the same accounting standards, these organizations were invited twice by e-mail to take part in our study by sending us their 2005 annual reports.

This year, 2005, marks the first year that all organizations were required to apply Swiss GAAP FER 21 standards. Swiss NPO that conduct social or humanitarian work can apply for the ZEWO seal. Thus, our sample covers only a small portion of the nonprofit sector in total. However, Kingma (1993) notes that results obtained "across categories may not be relevant within a category or for a group of similar nonprofits" (p. 113). We gathered information from a total of 203 organizations, and 193 were complete enough to use in a preliminary analysis. These data included the year of establishment, legal form, board size and number of women on the board, radius of activity (dummy for local, national, and international radius), sum of total assets as well as organizational capital, revenue from donations/government/own sources/ investments, and spending on projects/administrative tasks/fundraising. 


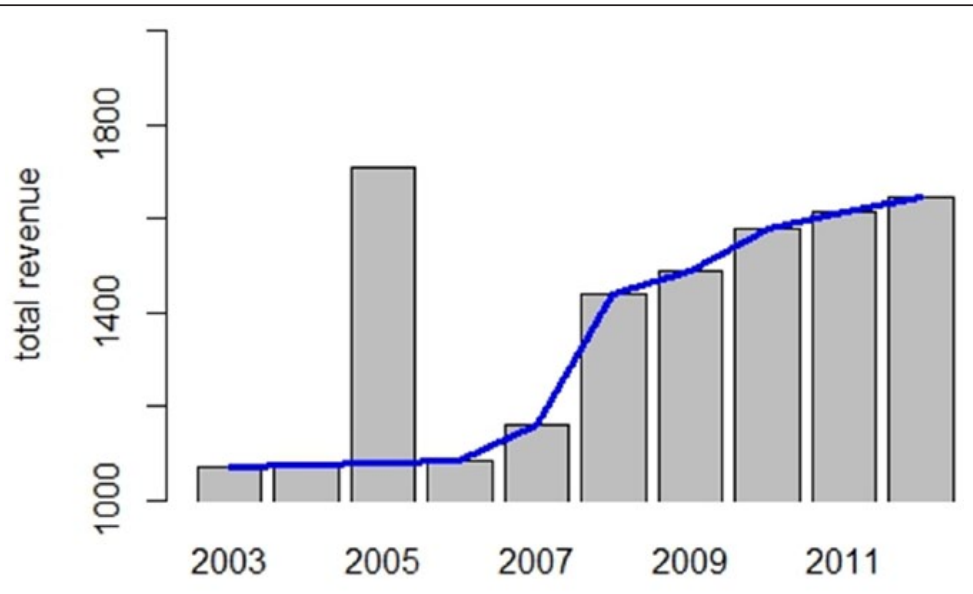

year

Figure I. Estimate of total donations (bars) and smoothed values (blue line), 2003-20I2 (in US\$I million).

Source. Based on ZEWO (20I3).

Among these organizations, two had to be excluded because of special effects, leaving us with 191 organizations. One of the excluded organizations was an outlier in 1 year due to selling shares of a subsidiary company, the second one was an outlier in terms of own revenues due to a specific insurance offered by this NPO only.

Table 1 presents general descriptive statistics about the size of these organizations. Unfortunately, in the year 2004, Southeast Asia and India were struck by the tsunami resulting from the Sumatra-Andaman earthquake. As a result, 2005 saw an unprecedented number of donations directed toward ZEWO organizations. This heavily affected revenue numbers in our sample. To account for this bias, revenue from donations from organizations with an international radius of activity were adjusted using interpolated values from estimated total countrywide donations from the years before and after 2005 (see Figure 1). This resulted in a 56\% reduction in revenue from donations to internationally active organizations. Furthermore, numbers from 2005 have been adjusted for 2012 inflation. Table 2 compares our data set with the official numbers ZEWO publishes annually.

Between 2005 and 2012 the adjusted revenue increase in our sample (+31\%) is identical to ZEWO-statistics (see Table 2). Our sample accounts for $64 \%$ (2005) and $65 \%$ (2012) of total reported ZEWO revenue and captures $44 \%$ of reporting organizations included in the annual statistics reported by ZEWO for 2005 and 2012.

Based on the two models and hypotheses introduced in the previous section, Table 3 gives an overview of the descriptive statistics of the variables, including minimum and maximum values, median and mean, and standard deviation. 
Table 2. Sources and Sum of Revenues of ZEWO-Certified Organizations in 2005 and 2012.

\begin{tabular}{clcccccc}
\hline & & & & & \multicolumn{3}{c}{ Total revenue } \\
& Year & Donations & Government & Own & Other & (in US\$1,000) & $n$ \\
\hline Complete & 2005 & $39 \%$ & $32 \%$ & $20 \%$ & $9 \%$ & $2,381,000$ & 437 \\
ZEWO & 2012 & $34 \%$ & $38 \%$ & $23 \%$ & $5 \%$ & $3,114,000$ & 431 \\
& Change & $-5 \%$ & $+6 \%$ & $+3 \%$ & $-4 \%$ & $+31 \%$ & $-1 \%$ \\
Sample & 2005 & $34 \%$ & $33 \%$ & $29 \%$ & $4 \%$ & $1,586,714$ & 191 \\
& 2012 & $35 \%$ & $36 \%$ & $27 \%$ & $2 \%$ & $2,071,610$ & 191 \\
& Change & $+1 \%$ & $+3 \%$ & $-2 \%$ & $-2 \%$ & $+31 \%$ & $0 \%$ \\
\hline
\end{tabular}

Source. ZEWO (2006) and ZEWO (20I3).

Table 3. Descriptive Statistics of Variables $(N=191)$.

\begin{tabular}{lrrrrr}
\hline Variable & Minimum & Median & \multicolumn{1}{c}{$M$} & Maximum & \multicolumn{1}{c}{$S D$} \\
\hline $\begin{array}{l}\text { Revenue growth (2005-20I2, } \\
\text { incl. investments) }\end{array}$ & 0.426 & 1.334 & 1.712 & 18.350 & 1.689 \\
RD(Yan).2005 & & & & & \\
Projectratio.2005 (incl. & 0.000 & 0.653 & 0.582 & 0.955 & 0.234 \\
$\quad$ investments) & 0.083 & 0.844 & 0.870 & 2.889 & 0.308 \\
Size.2005 (adj., incl. & & & & & \\
$\quad$ investments, in m CHF) & 0.051 & 2.268 & 8.307 & 167.200 & 17.774 \\
Agec & & & & & \\
RD(Yan).20I2a & 7.000 & 46.000 & 53.630 & 127.000 & 30.757 \\
Region.international (dummy) & 0.002 & 0.634 & 0.555 & 0.925 & 0.246 \\
Region.canton (dummy) & 0.000 & 0.000 & 0.278 & 1.000 & 0.449 \\
Foundation (dummy) & 0.000 & 0.000 & 0.330 & 1.000 & 0.471 \\
Size.20I2 (incl. investments, & 0.000 & 0.000 & 0.309 & 1.000 & 0.463 \\
$\quad$ in m USD) & 0.037 & 3.253 & 11.020 & 251.800 & 24.591 \\
Consistency (dummy) & & & & & \\
Board.diversity & 0.000 & 1.000 & 0.827 & 1.000 & 0.379 \\
Board.size & 0.000 & 0.889 & 0.792 & 1.000 & 0.225 \\
\hline
\end{tabular}

aExcluding three organizations that did not report full information necessary for the calculation of this variable.

bExpressed as (I+ growth) to allow for calculating the natural logarithm.

cExcluding one organization that did not report year of establishment.

To justify the application of a beta regression model, we additionally depict the density distribution of the second model's dependent variable in Figure 2. The accumulation of data points close to one of the unit interval's extremes thus becomes evident.

\section{Results}

In the following subsection, we present general findings regarding the revenue structures of Swiss fundraising NPOs and how they have changed over time. 


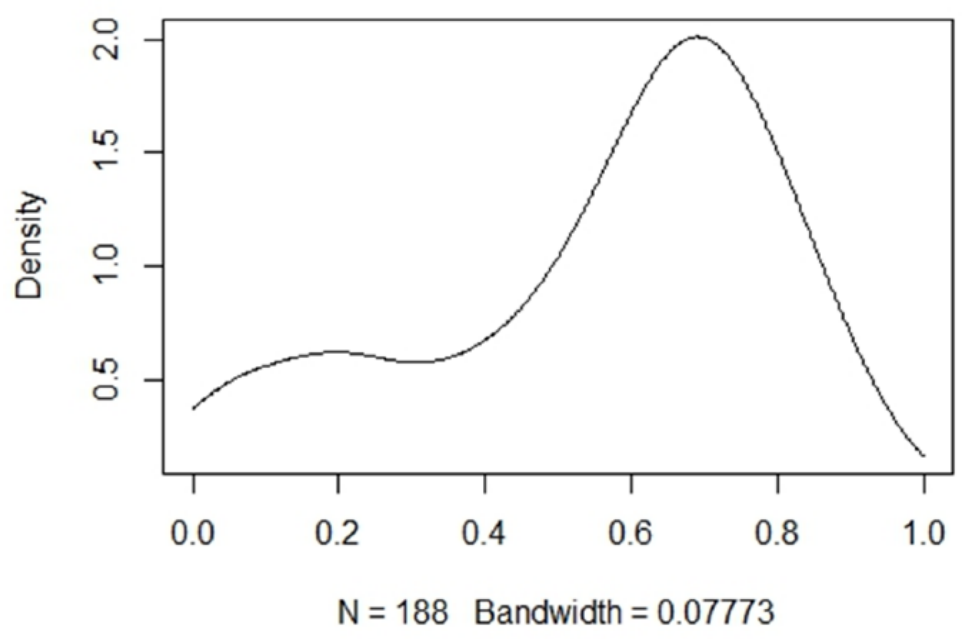

Figure 2. Density distribution of $\mathrm{RD}(\mathrm{Yan}) 20 \mathrm{I} 2$ (Gaussian kernel, bound in unit interval). Note. RD(Yan) 2012 has no observations at either zero or one.

Table 4. Primary Revenue Source 2005 Versus $2012(N=|9|)$.

\begin{tabular}{|c|c|c|c|c|c|}
\hline \multirow[b]{2}{*}{2005} & \multicolumn{3}{|c|}{2012} & \multirow[b]{2}{*}{ Total } & \multirow[b]{2}{*}{ Percentage } \\
\hline & Donations & Government & Own & & \\
\hline Donations & 77 & 6 & 8 & 91 & 47.6 \\
\hline Government & 6 & 42 & 6 & 54 & 28.3 \\
\hline Own & 5 & 4 & 37 & 46 & 24.1 \\
\hline Total & 88 & 52 & 51 & $N=191$ & \\
\hline Percentage & 46.1 & 27.2 & 26.7 & & \\
\hline Change & $-1.6 \%$ & $-1.0 \%$ & $+2.6 \%$ & & \\
\hline
\end{tabular}

Furthermore, we present the regression results for the two dependent variables: the $\log$ of 7-year growth of total revenues, as well as the degree of revenue diversification in 2012.

\section{General Findings}

In a preliminary analysis, we arranged the sample according to the primary revenue source at both points in time. The results, as shown in Table 4, support the fundamental assertion of the benefits theory of nonprofit finance, that is, nonprofits do not easily change the major income source. Although our data set covers a spectrum of 7 years, 
Table 5. Summary Regression Results_Determinants of NPOs Revenue Growth, 2005-20I 2.

\begin{tabular}{lccc}
\hline Coefficient & Estimate (SD) & $\operatorname{Pr}(>|\mathrm{t}|)$ & \\
\hline (Intercept) & $\mathrm{I} .4527(0.3348)$ & $2.37 \mathrm{E}-5$ & $* * *$ \\
$\mathrm{RD}($ Yan).2005 & $-0.323 \mathrm{I}(0.1547)$ & 0.0382 & $*$ \\
Projectratio.2005 & $0.3398(0.1140)$ & 0.0033 & $* *$ \\
Log(size.2005) - (adjusted, & $-0.0722(0.0226)$ & 0.0017 & $* *$ \\
$\quad$ including investments) & $-0.0026(0.0012)$ & 0.0315 & $*$ \\
Age & $.1859 * * *$ & & $* * *$ \\
Adjusted, $R^{2}$ & 11.62 & $2.016 \mathrm{E}-08$ & $* * 2$ \\
F-statistic (4/182) & & & \\
\hline
\end{tabular}

Note. NPO = nonprofit organization.

$*_{p}<.05 . * * p<.01 . * * * p<.001$.

there is a high consistency in the primary revenue source. As the sample covers fundraising organizations, it is not surprising that private donations are the most frequent primary revenue source. Despite the general debate on commercialization (Child, 2010), the data only report a slight shift from donations and government funds toward own revenues. However, due to the limitations of the data with only two data points, it is not appropriate to identify a trend.

\section{Revenue Growth}

In this section, we present the regression results for the dependent variable, the log of 7 -year revenue growth. As shown in Table 5, revenue diversification has a significantly negative influence on revenue growth $(-.3231 ; p=.05)$, thus rejecting H1.0 and supporting the findings of Chikoto and Neely (2014). For Swiss fundraising organizations, a concentration of revenue sources increases their overall financial revenue. The findings are statistically significant at the 5\% level, offering no evidence for resource dependency theory. In addition, the amount of revenue spent on projects has a significantly positive influence on revenue growth, thus rejecting $\mathrm{H} 2.0$. Hence, with higher project expenditures, financial revenues grow by $34 \%(p=.01)$. These results are in line with assumptions about competitive advantage, meaning that higher project expenditures serve both clients and donors. However, we cannot confirm Chikoto and Neely's (2014) finding that increasing administrative costs have a positive influence on financial growth. When included in the model, administrative costs had a negative but not significant influence.

The results of the control variables are statistically significant as well. The size of an organization has a significantly negative influence on revenue growth, making it harder for large NPOs to show high growth rates. The age of an organization has a significantly negative influence on revenue growth, too. This means that younger organizations were able to grow more strongly than older ones. As a primary conclusion, one can say that costs of financial growth increase with size and age. 
Table 6. Summary Regression Results-Determinants of NPO Revenue Diversification, 2012.

\begin{tabular}{lccc}
\hline Coefficient & Estimate (SD) & $\operatorname{Pr}(>|\mathrm{z}|)$ & $*$ *** \\
\hline (Intercept) & $-2.7849(0.8 I 12)$ & 0.0006 & $*$ \\
Region.international & $-0.4195(0.1701)$ & 0.0014 & $\dagger$ \\
Region.canton & $0.3053(0.1715)$ & 0.0750 & $* .2067$ \\
Foundation & $-0.2003(0.1586)$ & 0.0007 & $* * *$ \\
Log(size.20I2) & $0.1692(0.0501)$ & 0.0003 & $*$ \\
Consistency & $-0.6584(0.1825)$ & 0.0205 & $* *$ \\
Board.diversity & $0.7330(0.3163)$ & 0.0029 & $* * *$ \\
Board.size & $0.0431(0.0145)$ & & $* 2 \mathrm{E}-16$ \\
Pseudo $R^{2}$ & .2013 & & $*$ \\
Phi & 3.5598 & & \\
\hline
\end{tabular}

Note. NPO = nonprofit organization.

$t_{p}<.10 . *_{p}<.05 . *_{p}<.01$. $* * * p<.001$.

\section{Drivers Behind Diversification of Revenue Structure}

In our second regression model, we test the influence of nature and nurture factors on revenue diversification (see Table 6). When looking at the nature factors. the two dummy variables for geographical radius of activity both show significant influence on revenue diversification, on at least the $p=.10$ level, thus rejecting H3.0. Based on a nationwide radius of activity as reference, the wider the radius of activity, the higher the degree of concentration on certain sources of revenue.

Given our regression analysis, H4.0 could not be rejected, meaning we found no significant influence of the legal form of an organization on the degree of revenue diversification. The reason might be that income from member fees is less relevant for NPOs in our sample.

Organizational size, measured by total revenues, has a significantly positive influence on the degree of revenue diversification, thus rejecting H5.0. Given that size can be perceived as a proxy for professionalization, revenue diversification might be driven by professionalization.

The three nurture factors are all statistically significant in our model. Consistency in the primary source of revenue over time has a highly significant negative influence on revenue diversification, thus rejecting H6.0. Organizations that did not show shifts in their primary source of income over time therefore tend to concentrate on that specific source.

Board diversity, measured as an adjusted HHI between male and female board members, had a significantly positive influence on revenue diversification, thus rejecting H7.0. Board size also had a significantly positive influence on revenue diversification, thus rejecting H8.0. Hence, a more diversified and larger board leads to higher diversification of revenue sources as well. This can be explained through the larger networks and heterogeneous mind-set of such a board. 


\section{Discussion}

The findings presented in the previous section add to the recent debate on revenue diversification (Chikoto \& Neely, 2014; Lecy \& Searing, 2015; Tevel et al., 2015). In light of resource dependency theory, revenue diversification has been used as a measure of financial stability and as an explanatory factor for financial health. Thus, revenue diversification was always used as an independent variable, understood as an active management choice. However, Wilsker and Young (2010) have shown that "revenue sources are associated with the mix of programs offered by a nonprofit" ( $p$. 209). We further developed this stream of theory by adding the influence of nature and nurture on different factors in revenue diversification.

One major finding of this research is the positive influence of revenue concentration on financial growth. Thus, we support the argument of Chikoto and Neely (2014) that financial health consists of both stability and capacity. When NPOs only focus on financial stability, they actively refuse to grow. Stability may reduce volatility and increase predictability, but it is not a mechanism for increasing revenues. Even more, a nonprofit may risk entering a starvation cycle, resulting in falling overhead ratios (Lecy \& Searing, 2015). However, our findings also suggest that higher project expenditures lead to financial growth, while administrative expenditures show no significant influence on financial growth. Thus, solely reducing administrative costs does not increase financial growth. Instead, we build our explanation on the competitive advantage theory, meaning that donors are less interested in administrative cost ratios and more interested in project investments and results. Hence, NPOs can expect higher revenues in the future if they explore and pursue their projects. Another reason may be the structure of our sample in which a majority of NPO primarily relies on contributions instead of their own revenue sources. Thus, one of this paper's recommendations for how to exploit growth potential is to encourage awareness of the nature and nurture factors that drive revenue structure.

By referring to the notion of nature versus nurture, we investigated the drivers of revenue diversification. Both nature and nurture factors have a significant influence on diversification. Following the theory, nature factors, such as activity range or size, influence the degree of diversification but cannot be changed. It is a somewhat contradictory result that more international organizations become concentrated and larger organizations become more diversified. Usually, one would expect size and activity range to interfere. One explanation might be that Swiss international aid organizations rely heavily on government funds without many options for substitution.

In contrast, fundraising methods, board composition, and board size are factors that can be actively influenced. These findings are in line with previous work by Jegers (2011), emphasizing the influence of revenue constraints and agency problems for nonprofit capital structure. In addition, these results offer important insights for practitioners.

Although our data consisted of only two points in time, there are some interesting findings in terms of financial development. First, revenue concentration increased 
over time. This may be a result of specification and learning. A young nonprofit with an innovative mission approach may find financial support from different sources. However, with ongoing operations, only a few revenue sources will prove to be stable and predictable over time. Second, despite the high consistency of the primary income source, a shift toward commercial revenues can be detected. Aside from the rationing of government funds, this might be a result of blurring boundaries between the sectors. Finally, our 7-year sample provides evidence of the ongoing growth of the nonprofit sector in Switzerland at large. We cannot report either stagnation or decline of overall revenues in the Swiss nonprofit sector. In addition, our sample consists of nonprofits that rely heavily on private donations. Thus, philanthropic action is of high relevance to society.

As a conclusion, revenue diversification and concentration are not perfect substitutes for each other and NPOs do not have to pursue either one or the other. In line with Bowman's (2011) definition of financial health, which consists of stability and capacity, our results provide evidence that both aspects have to be simultaneously included in managerial decisions, as the optimal revenue structure is influenced by many different factors of nature and nurture.

\section{Outlook}

Before addressing some implications for further research and practice, we should highlight some limitations of our study. First of all, our sample does not allow for simple generalization about the nonprofit sector at large or in an international context. As we only captured Swiss fundraising organizations in the areas of social service and development aid, we must be aware of the specifics of these organizations. However, in the public's perception, they represent the "typical" nonprofit. In addition, our data set is limited, as it only covers two points in time. Inclined to cover a long time period, we choose the first and the last available time periods with consistent accountability reporting standards. A downside of this approach was the problem of the high number of donations in the wake of the tsunami catastrophe in 2005. Thus, future studies should be based on time series data, allowing the application of portfolio theory-based calculations of the degree of diversification and covariance between sources of income. Finally, we are aware that our data set is not as elaborated as some other data sets of U.S. origin. This originates from a lack of available data in the annual reports of Swiss nonprofits and is a limitation that cannot be immediately removed.

Despite these limitations, our research adds to the further development of a theory of nonprofit capital and revenue structure. Future research should further investigate the drivers of revenue diversification. Building on Wilsker and Young (2010) and our study, additional determinants of revenue diversification should be detected. This stream of research would fill the gap between nonprofit operations and nonprofit revenues. So far, the two areas - colloquially known as mission and fundraising — have been analyzed without much attention to their interactions.

We further call for a revision of the resource dependency paradigm. More research should concentrate on revenue concentration and developments in the direct 
environment of the nonprofit sector. Research on social entrepreneurship and social businesses offers interesting insights on the mix of mission and market orientations that might be helpful in developing the nonprofit sector.

With regard to the practical implications of our research, we emphasize the distinction between nature and nurture. Nonprofit managers should analyze these factors when planning their organizations' mix of financial resources. Size, activity range, or legal form cannot be changed quickly, but they have an impact on capital structure. Being aware of these influences, nonprofit managers should address the nurture factor so as to compensate for the influences of the other drivers and direct the capital structure according to the chosen strategy. Board composition and structure play an important role in that respect (Brown, 2005).

In addition, NPOs should develop a model of financial health that includes strategies for both financial stability and capacity. Rewarding the relative proportion of revenue dedicated to project spending (as a positive driver of revenue growth) challenges NPOs, as the accumulation of unrestricted assets reduces the vulnerability of NPOs (see Calabrese, 2012). They seem to be able to grow in terms of total annual revenues but not in terms of organizational and unrestricted assets. To sum up, revenue diversification is only a means to an end, and low overhead ratios may create more severe damage than a clear investment strategy acknowledging that future growth requires higher expenditures in the present. In that sense, we comply with Froelich (1999): "The ultimate goal is continued pursuit of the charitable mission" (p. 263).

\section{Acknowledgments}

The authors thank Martin Schweighoffer for his support in the data collection.

\section{Declaration of Conflicting Interests}

The author(s) declared no potential conflicts of interest with respect to the research, authorship, and/or publication of this article.

\section{Funding}

The author(s) received no financial support for the research, authorship, and/or publication of this article.

\section{Note}

1. Using R statistical software: http://cran.r-project.org/

\section{References}

Bies, A. L. (2010). Evolution of nonprofit self-regulation in Europe. Nonprofit and Voluntary Sector Quarterly, 39, 1057-1086.

Bowman, W. (2006). Should donors care about overhead costs? Do they care? Nonprofit and Voluntary Sector Quarterly, 35, 288-310.

Bowman, W. (2011). Financial capacity and sustainability of ordinary nonprofit. Nonprofit Management \& Leadership, 22, 37-51. 
Brown, W. A. (2005). Exploring the association between board and organizational performance in nonprofit organizations. Nonprofit Management \& Leadership, 15, 317-339.

Calabrese, T. (2011). Testing Competing Capital Structure Theories of Nonprofit Organizations. Public Budgeting \& Finance, 31, 119-143.

Calabrese, T. (2012). The accumulation of nonprofit profits: A dynamic analysis. Nonprofit and Voluntary Sector Quarterly, 41, 300-324.

Carroll, D. A., \& Stater, K. J. (2009). Revenue diversification in nonprofit organizations: Does it lead to financial stability? Journal of Public Administration Research and Theory, 19, 947-966.

Carter, D. A., Simkins, B. J., \& Simpson, W. G. (2003). Corporate governance, board diversity, and firm value. The Financial Review, 38, 33-53.

Chang, C. F., \& Tuckman, H. P. (1994). Revenue diversification among nonprofits. VOLUNTAS: International Journal of Voluntary and Nonprofit Organizations, 5, 273-290.

Chikoto, G. L., \& Neely, D. G. (2014). Building nonprofit financial capacity: The impact of revenue concentration and overhead costs. Nonprofit and Voluntary Sector Quarterly, 43, 570-588.

Child, C. (2010). Wither the turn? The ambiguous nature of nonprofit's commercial revenue. Social Forces, 89, 145-162.

Eberle, R., \& Müller, K. (2011). Swiss GAAP FER 21. Zürich, Switzerland: Verlag SKV.

Ferrari, S., \& Cribari-Neto, F. (2004). Beta regression for modelling rates and proportions. Journal of Applied Statistics, 31, 799-815.

Foster, W., \& Fine, G. (2007). How nonprofits get really big. Stanford Social Innovation Review, 5(2), 45-55.

Froelich, K. A. (1999). Diversification of revenue strategies: Evolving resource dependence in nonprofit organisations. Nonprofit and Voluntary Sector Quarterly, 28, 246-268.

Frumkin, P., \& Andre-Clark, A. (2000). When mission, markets, and politics collide: Values and strategy in the nonprofit human services. Nonprofit and Voluntary Sector Quarterly, 29, 141-163.

Frumkin, P., \& Keating, E. K. (2011). Diversification reconsidered: The risks and rewards of revenue concentration. Journal of Social Entrepreneurship, 2, 151-164.

Galaskiewicz, J., Bielefeld, W., \& Dowell, M. (2006). Networks and organizational growth: A study of community based nonprofits. Administrative Science Quarterly, 51, 337-380.

Hager, M. A., \& Brudney, J. L. (2011). Problems recruiting volunteers: Nature versus nurture. Nonprofit Management \& Leadership, 22, 137-157.

Helmig, B., Gmür, M., Bärlocher Ch von Schnurbein, G., Degen, B., Nollert, M., Budowski, M., . . Salamon, L. M. (2011). The Swiss civil society sector in comparative perspective. Fribourg, Switzerland: Verbands Management Institut.

Hwang, H., \& Powell, W. W. (2009). The rationalization of charity: The influences of professionalism in the nonprofit sector. Administrative Science Quarterly, 54, 268-298.

James, E. (1983). How nonprofits grow: A model. Journal of Policy Analysis and Management, 2, 350-366.

Jegers, M. (2011). On the capital structure of non-profit organisations: A replication and extension with Belgian data. Financial Accountability \& Management, 27, 18-31.

Jegers, M. (2013). Do nonprofit organisations manage earnings? An empirical study. VOLUNTAS: International Journal of Voluntary and Nonprofit Organizations, 24, 953-968.

Jegers, M., \& Verschuren, I. (2006). On the capital structure of non-profit organisations: An empirical study for Californian organisations. Financial Accountability \& Management, $22,309-329$. 
Kieschnicke, R., \& McCullough, B. D. (2003). Regression analysis of variates observed on (0, 1): Percentages, proportions and fractions. Statistical Modelling, 3, 193-213.

Kingma, B. R. (1993). Portfolio theory and nonprofit financial stability. Nonprofit and Voluntary Sector Quarterly, 22, 105-119.

Kong, E., \& Prior, D. (2008). An intellectual capital perspective of competitive advantage in nonprofit organisations. International Journal of Nonprofit and Voluntary Sector Marketing, 13, 119-128.

Lecy, J. D., \& Searing, E. A. M. (2015). Anatomy of the nonprofit starvation cycle: An analysis of falling overhead ratios in the nonprofit sector. Nonprofit and Voluntary Sector Quarterly, 44, 539-563.

Lu, J. (2015). Which nonprofit gets more government funding? Nonprofit Management \& Leadership, 25, 297-312.

Mayer, W. J., Wang, H., Egginton, J., \& Flint, H. S. (2014). The impact of revenue diversification on expected revenue and volatility for nonprofit organizations. Nonprofit and Voluntary Sector Quarterly, 43, 374-392.

McDonald, R. E. (2007). An investigation of innovation in nonprofit organizations: The role of organizational mission. Nonprofit and Voluntary Sector Quarterly, 36, 256-281.

Miller-Millesen, J. L. (2003). Understanding the behavior of nonprofit boards of directors: A theory-based approach. Nonprofit and Voluntary Sector Quarterly, 32, 521-547.

Ortmann, A., Svítková, K., \& Krnáčová, A. (2005, March). Certification as a viable quality assurance mechanism: Evidence, theory, and open questions (Working Paper No. 288). Prague: Center for Economic Research and Graduate Education and Transparency International, Charles University and Economics Institute of the Academy of Sciences of the Czech Republic.

Pfeffer, J., \& Salancik, G. R. (2003). The external control of organizations: A resource dependence perspective. New York, NY: Stanford University Press.

Porter, M. E. (1985). The competitive advantage: Creating and sustaining superior performance. New York, NY: The Free Press.

Purtschert, R., von Schnurbein, G., \& Bittel, N. (2007). Charity-Gala oder Sammelbüchse? [Charity gala or collecting box?] Verbands-Management, 33(2), 36-45.

Salamon, L. M., \& Anheier, H. K. (1996). Social origins of civil society: Explaining the nonprofit sector cross-nationally (Working Papers of the Johns Hopkins Comparative Nonprofit Sector Project, No. 22). Baltimore, MD: The Johns Hopkins Institute for Policy Studies.

Schober, Ch., Littich, E., Schober, D., \& Lintschinger, L. (2011). Die unterschiedlichen Finanzierungsquellen von NPO [Different financial resources of NPO]. Wien, Austria: WU Wien.

Siciliano, J. I. (1996). The relationship of board member diversity to organizational performance. Journal of Business Ethics, 15, 1313-1320.

Steinberg, R. (1993). Public policy and the performance of nonprofit organizations: A general framework. Nonprofit and Voluntary Sector Quarterly, 22, 13-31.

Suarez, D. F. (2011). Collaboration and professionalization: The contours of public sector funding for nonprofit organizations. Journal of Public Administration Research and Theory, 21, 307-326.

Tevel, E., Katz, H., \& Brock, D. M. (2015). Nonprofit financial vulnerability: Testing competing models, recommended improvements, and implications. VOLUNTAS: International Journal of Voluntary and Nonprofit Organizations, 26, 2500-2516.

Tuckman, H., \& Chang, C. (1991). A methodology for measuring the financial vulnerability of charitable nonprofit organizations. Nonprofit and Voluntary Sector Quarterly, 20, 445-460. 
von Schnurbein, G. (2013). Der Nonprofit-Sektor in der Schweiz [The nonprofit sector of Switzerland]. In R. Simsa, M. Meyer, \& Ch. Badelt (Eds.), Handbuch der NonprofitOrganisationen (pp. 37-54). Stuttgart, Germany: Schäffer-Poeschl.

von Schnurbein, G. (2016). Manageing impact and recognising success. In T. Jung, S. Phillips, \& J. Harrow (Eds.), The Routledge companion to philanthropy (pp. 468-481). London, England: Routledge.

von Schnurbein, G., \& Timmer, K. (2015). Die Förderstiftung. Strategie-FührungManagement [The grant-making foundation. Strategy — leadership — management] (2nd ed.). Basel, Switzerland: Helbing Lichtenhahn Verlag.

Warnaby, G., \& Finney, J. (2005). Creating customer value in the not-for-profit sector: A case study of the British Library. International Journal of Nonprofit and Voluntary Sector Marketing, 10, 183-195.

Wicker, P., \& Breuer, C. (2014). Examining the financial condition of sport governing bodies: The effects of revenue diversification and organizational success factors. VOLUNTAS: International Journal of Voluntary and Nonprofit Organizations, 25, 929-948.

Wicker, P., Longley, N., \& Breuer, C. (2015). Revenue Volatility in German Sports Clubs. Nonprofit and Voluntary Sector Quarterly, 44, 5-24.

Wilsker, A. L., \& Young, D. R. (2010). How does program composition affect the revenues of nonprofit organizations? Investigating a benefits theory of nonprofit finance. Public Finance Review, 38, 193-216.

Yan, W., Denison, D. V., \& Butler, J. S. (2009). Revenue structure and nonprofit borrowing. Public Finance Review, 37, 47-67.

Zeileis, A., Cribari-Neto, F., Gruen, B., \& Kosmidis, I. (2015). Package “betareg.” Retrieved from http://cran.r-project.org/web/packages/betareg/betareg.pdf

ZEWO. (2006). Spendenrekord im Jahr 2005 [Record level of donations in 2005]. Zewoforum, $3.2006,6-8$.

ZEWO. (2013). Das ZEWO-Gütesiegel verhilft zu Spendenwachstum [Zewo-seal strengthens donantion growth]. Zewoforum, 3.2013, 4-6.

ZEWO. (2015). ZEWO foundation. Retrieved from https://zewo.ch/en/

\section{Author Biographies}

Georg von Schnurbein, $\mathrm{PhD}$, is associate professor of foundation management and director of the Center for Philanthropy Studies (CEPS), University of Basel. He is author of various publications on subjects such as foundations, governance, and nonprofit management and marketing.

Tizian M. Fritz, PhD, is scientific advisor for the Swiss Science and Innovation Council (SSIC) and research fellow at the CEPS, University of Basel. His research focus at the CEPS is mission investing and financial management of nonprofit organizations (NPOs). 